\title{
Effects of the amount and quality of dietary protein on nitrogen metabolism and protein turnover of pigs
}

\author{
By M. F. FULLER, P. J. REEDS*, A. CADENHEAD AND B. SEVE† \\ Rowett Research Institute, Bucksburn, Aberdeen AB2 9SB \\ AND T.PRESTON \\ Scottish Universities Research Reactor Centre, East Kilbride, Glasgow G75 0QU
}

(Received 29 January 1987 - Accepted 20 March 1987)

\begin{abstract}
1. The interrelations between protein accretion and whole-body protein turnover were studied by varying the quantity and quality of protein given to growing pigs.

2. Diets with 150 or $290 \mathrm{~g}$ lysine-deficient protein $/ \mathrm{kg}$ were given in hourly meals, with or without lysine supplementation, to female pigs (mean weight $47 \mathrm{~kg}$ ).

3. After the animals were adapted to the diets, a constant infusion of $\left[{ }^{14} \mathrm{C}\right]$ urea was given intra-arterially for $30 \mathrm{~h}$, during the last $6 \mathrm{~h}$ of which an infusion of $\left[4,5-{ }^{3} \mathrm{H}\right]$ leucine was also infused at a constant rate. At the same time, yeast-protein labelled with ${ }^{15} \mathrm{~N}$ was given in the diet for $50 \mathrm{~h}$.

4. The rate of urea synthesis was estimated from the specific radioactivity (SR) of plasma urea. The rate of leucine flux was estimated from the SR of plasma leucine. The irrevocable breakdown of leucine was estimated from the ${ }^{3} \mathrm{H}$-labelling of body water. Total $\mathrm{N}$ flux was estimated from the ${ }^{15} \mathrm{~N}$-labelling of urinary urea.

5. Addition of lysine to the low-protein diet significantly increased $\mathrm{N}$ retention, with a substantial reduction in leucine breakdown, but there was no significant change in the flux of leucine or of total $\mathrm{N}$.

6. Increasing the quantity of the unsupplemented protein also increased $\mathrm{N}$ retention significantly, with concomitant increases in leucine breakdown and in the fluxes of leucine and of total $\mathrm{N}$.

7. It is concluded that a doubling of protein accretion brought about by the improvement of dietary protein quality is not necessarily associated with an increased rate of whole-body protein turnover.
\end{abstract}

The energy cost of growth, that is, the increase in food energy required to promote a unit increase in growth, greatly exceeds the heat of combustion of the tissue formed. The energy cost of protein accretion by growing pigs has been estimated to be $44 \mathrm{~kJ} / \mathrm{g}$ (Agricultural Research Council, 1981). The heat of combustion of mixed body proteins is $23.7 \mathrm{~kJ} / \mathrm{g}$ so that each $1 \mathrm{~g}$ protein accretion apparently involves the expenditure of approximately $20 \mathrm{~kJ}$ $(44-23 \cdot 7)$. The energy expended in protein synthesis, on the other hand, is generally estimated to be $3.5 \mathrm{~kJ} / \mathrm{g}$ (Millward et al. 1976). In previous work with growing pigs (Reeds et al. 1980) the rate of protein synthesis was found to increase by $2 \cdot 2 \mathrm{~g}$ for each $1 \mathrm{~g}$ increase in the rate of protein accretion. From these experiments and others in which single nutrients were varied (Reeds et al. 1981) we suggested that the energy expended in protein synthesis could account for only part of the energy cost of protein accretion. In those experiments the changes in protein accretion were achieved by large changes in energy intake or protein intake or both. To discover whether increases in protein accretion are invariably linked to changes in whole-body protein synthesis and heat production, we have now examined the effects of doubling the rate of protein accretion with virtually no change in energy or protein intake by increasing the supply of the limiting amino acid in an imbalanced protein. The effects on heat production were described in the previous paper (Fuller et al. 1987a); the measurements of protein turnover and amino acid metabolism are presented here. Some preliminary results of this work have been presented briefly (Fuller et al. 1987 b).

Present addresses: *USDA/ARS Children's Nutrition Research Centre, Department of Pediatrics, Baylor College of Medicine, Medical Towers Building, Suite 1501, Fannin Street, Houston 77030, Texas, USA. †Station de recherches porcines, Saint-Gilles, 35590 L'hermitage, France. 


\section{MATERIAL AND METHODS}

\section{Animals}

Large White $\times$ (Large White $\times$ Landrace) female pigs of $17-22 \mathrm{~kg}$ had two catheters introduced under Halothane anaesthesia into the lumbar aorta via the medial saphenous arteries, one in each leg. The catheters were of PVC, $1.0 \mathrm{~mm}$ internal and $1.6 \mathrm{~mm}$ external diameter (NT2; Portex, Ltd, Hyde, Kent). The catheters were inserted to lengths of approximately 250 and $400 \mathrm{~mm}$ : the longer one, its tip nearer the heart, was used for sampling, the shorter, its tip distal to the renal artery, for infusion. The position of each catheter was checked under X-ray. The catheters were then anchored at the point of insertion into the saphenous artery and the free ends were led subcutaneously to emerge on the animal's back. The animals were allowed at least $10 \mathrm{~d}$ to recover before the infusions were started. Their mean weight during the experiments was $47 \mathrm{~kg}$.

\section{Diets and feeding}

The diets were the same as those used in the previous experiment described by Fuller et al. (1987 a) where details of their composition are given. The primary diet (diet 3; HP - ) had a high content $(290 \mathrm{~g} / \mathrm{kg})$ of lysine-deficient protein. This was diluted with non-protein ingredients to give a diet (diet $1 ; \mathrm{LP}-$ ) with half the protein and lysine contents. Each of these diets was also given with a supplement of L-lysine hydrochloride sufficient to raise the lysine content of diet 1 to that of diet 3 . These supplemented diets were designated $2(\mathrm{LP}+)$ and $4(\mathrm{HP}+)$. All the diets were prepared from the same batches of ingredients as those described in the previous paper (Fuller et al. 1987a) and were similar in composition (Table 1). All four diets were given at a daily rate of $110 \mathrm{~g} / \mathrm{kg}$ body-weight $(\mathrm{W})^{0.75}$, but to ensure a reasonably steady state of nutrient absorption they were given in twenty-four equal hourly meals by means of automatic dispensers.

\section{Design}

It was originally intended that eight pigs should receive each diet in four successive periods in two Latin squares. In the event, only seven pigs completed four periods and for some of these animals the results were incomplete for a variety of minor technical reasons. Accordingly, a further seven observations were made with three more pigs to furnish more information, giving a total of thirty-six observations in all, except for the ${ }^{15} \mathrm{~N}$ values, for which there were only twenty in all. The distribution of these amongst the treatments is indicated in the tables of results.

Each period lasted for 2 weeks, during all of which the pig was given a constant daily intake of the appropriate diet. During the first 4 or $5 \mathrm{~d}$ the pig was housed in a loose pen, when it was fed twice daily; then it was put into a metabolism cage and fed once hourly by means of an automatic feeder with twenty-four small containers on a belt which moved forward every hour to tip one container. On the 6th day a bladder catheter was introduced and the following day a complete collection of urine and faeces was started and continued for $7 \mathrm{~d}$. Faeces and urine were each collected directly into sulphuric acid.

\section{Infusions}

At 10.00 hours on day 11 a continuous infusion of $\left[{ }^{14} \mathrm{C}\right]$ urea was begun. The infusion solution contained approximately $5 \mu \mathrm{Ci}\left[{ }^{14} \mathrm{C}\right]$ urea and was infused at a constant rate of $0.38 \mathrm{ml} / \mathrm{h}$ over $30 \mathrm{~h}$. At 10.00 hours on day 12 this sólution was replaced by one containing both $\left[{ }^{14} \mathrm{C}\right]$ urea and $\left[4,5-{ }^{3} \mathrm{H}\right]$ leucine. This combined infusion was continued for $6 \mathrm{~h}$. Details of the infusion schedule are shown in Fig. 1. 
Table 1. Composition of the diets, the formulations of which are given in a previous paper (Fuller et al. 1987a)

\begin{tabular}{lcccc}
\hline Diet $\ldots$ & 1 & 2 & 3 & 4 \\
& LP - & LP + & HP - & HP + \\
\hline Dry matter $(\mathrm{g} / \mathrm{kg})$ & 882 & 886 & 885 & 875 \\
Nitrogen $\times 6.25(\mathrm{~g} / \mathrm{kg})$ & 147 & 154 & 295 & 286 \\
Total lysine $(\mathrm{g} / \mathrm{kg})^{*}$ & $3 \cdot 7$ & 7.4 & 7.4 & 11.1 \\
Total leucine $(\mathrm{g} / \mathrm{kg})^{*}$ & 9.9 & 10.3 & 19.8 & $19 \cdot 2$ \\
\hline
\end{tabular}

LP, Low-protein; HP, high-protein; +,-, with or without lysine supplementation respectively.

* Calculation from amino acid analyses of ingredients.
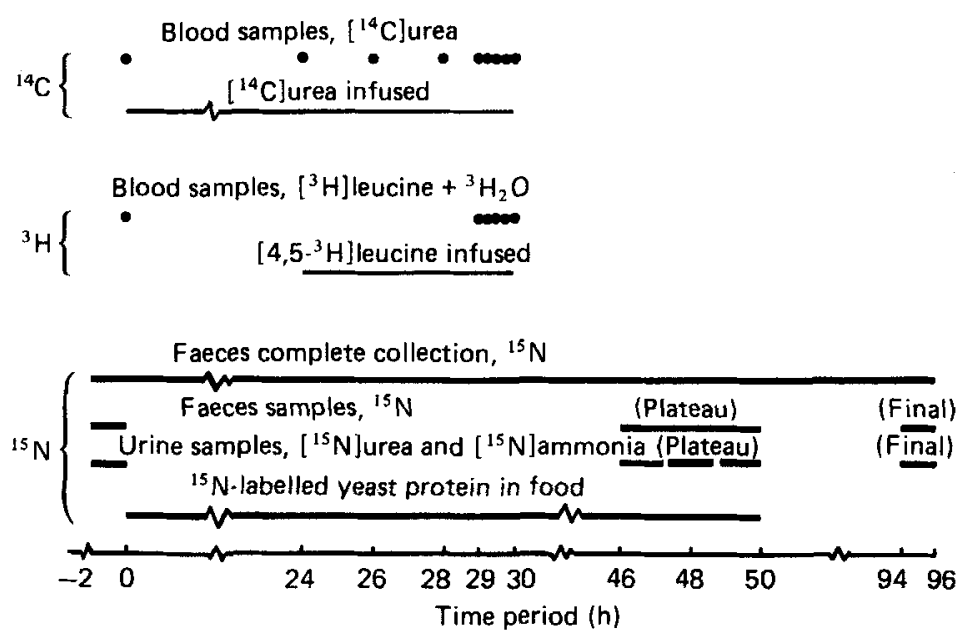

Fig. 1. Diagram showing the relative times of label administration and of blood, urine and faeces samples.

\section{${ }^{15} \mathrm{~N}$-labelled yeast protein}

Semi-purified, nucleic acid-free yeast-protein, containing more than $97 \%$ of its ${ }^{15} \mathrm{~N}$ in amino acids labelled to $950 \mathrm{~g}$ atoms $/ \mathrm{kg} \mathrm{N}$, was mixed with $0.1 \mathrm{M}$ sodium hydroxide $(7 \mathrm{mg}$ yeast-protein $/ \mathrm{ml}$ ). This was incubated overnight at $37^{\circ}$ and mixed with $0.1 \mathrm{M}$-hydrochloric acid $(0.95 \mathrm{ml} / \mathrm{ml}$ yeast solution). This mixture was added to the food at the rate of $0.5 \mathrm{ml}$ to each of fifty of the hourly meals, starting at 10.00 hours on day 11 . The preparation supplied approximately $0.30 \mathrm{mg}$ excess ${ }^{15} \mathrm{~N} / \mathrm{h}$.

\section{${ }^{15} N$ analysis}

Urine-ammonium was separated by direct distillation into boric acid-indicator solution after addition of $1 \mathrm{~g}$ magnesium oxide $/ 25 \mathrm{ml}$ urine. Urinary urea was treated similarly after hydrolysis with urease (EC 3.5.1.5) (Preston \& East, 1982). The batch cation-exchangeresin method of Read et al. (1982) was followed on later samples.

Faecal and ileal digesta underwent Kjeldahl digestion and ammonia was distilled into boric acid-indicator solution. Some later faecal samples were analysed by Dumas combustion with an elemental analyser-isotope ratio mass-spectrometer apparatus (Preston \& Owens, 1983). Otherwise, $\mathrm{N}_{2}$ gas was liberated from sample ammonium by oxidation 
with lithium hypobromite in the inlet system of a VGMM602B isotope-ratio mass spectrometer (VG Isogas, Middlewich, Cheshire) operated in a single-inlet mode. Repeatability of analysis (1 SD) was 0.0007 atom $\%{ }^{15} \mathrm{~N}$ for urine samples and 0.0019 atom $\%{ }^{15} \mathrm{~N}$ for faecal samples.

\section{Digestibility of ${ }^{15} \mathrm{~N}$}

To estimate the amount of ${ }^{15} \mathrm{~N}$ absorbed during administration of the labelled yeast protein, two studies were made with each of three pigs, which did not form part of the main experiment. These three animals all had simple ' $T$ ' cannulas $(18 \mathrm{~mm}$ i.d.) introduced into the terminal ileum approximately $150 \mathrm{~mm}$ from the ileo-caecal junction. The surgery was done under Halothane anaesthesia at least 6 weeks before measurements were made. In each study ${ }^{15} \mathrm{~N}$-labelled yeast protein was administered once hourly, just as in the main experiment, for $48 \mathrm{~h}$. As an indigestible marker, chromic oxide $(5 \mathrm{~g} / \mathrm{kg})$ was also included in the food. Samples of ileal digesta were collected from 5-9, 9-13, 29-33 and 33-37 h after the start of administration. Their dry matter, $\mathrm{N}$ and chromium contents were estimated, as well as the abundance of ${ }^{15} \mathrm{~N}$.

\section{Sample preparation and analysis}

Blood samples $(10 \mathrm{ml})$ were divided into two $5 \mathrm{ml}$ parts. One was injected into an evacuated tube $(25 \mathrm{ml}$ ) containing $1 \mathrm{ml} \mathrm{2.5} \mathrm{M}$-perchloric acid (PCA) with $1.25 \mu \mathrm{mol} \mathrm{L}$-norleucine. The other part was injected into a sealed tube and centrifuged at $3000 \mathrm{rev} . / \mathrm{min}$ for $10 \mathrm{~min}$. An accurately weighed portion (about $0.5 \mathrm{~g}$ ) of the plasma was transferred to a scintillation vial and a second weighed portion (about $1 \mathrm{~g}$ ) to a pre-weighed bottle. Separate samples of plasma were taken for the analysis of urea (Marsh et al. 1965), insulin (Bassett \& Thorburn, 1971) and cortisol (Amertex IM2021 Kit; Amersham International plc, Amersham, Bucks). The sample of whole blood in PCA was frozen until analysed for leucine concentration and specific radioactivity (SR) as described by Reeds et al. (1980). The sample of plasma in the weighed bottle was lyophilized for $48 \mathrm{~h}$, reweighed and reconstituted in $1 \mathrm{ml}$ of water. A weighed portion was taken for scintillation counting.

\section{Other analytical methods}

$\mathrm{N}$ was estimated by Kjeldahl digestion followed by automated analysis of ammonia as described by Davidson et al. (1970). Urea was estimated by the method of Marsh et al. (1965) and $\mathrm{NH}_{3}$ by the procedure of Fawcett \& Scott (1960).

\section{Calculations}

1. SR of urea and water. The SR of plasma urea was taken as:

$$
{ }^{14} \mathrm{C}(\mathrm{Bq}) / \text { urea concentration. }
$$

Preliminary experiments had established that all the ${ }^{14} \mathrm{C}$ radioactivity remained in urea. The ${ }^{3} \mathrm{H}_{2} \mathrm{O}$ SR was calculated as follows. The loss of weight on lyophilization of a plasma sample was taken to equal the water content of the plasma and the loss of radioactivity as that of the plasma water. This procedure removed more than $99.5 \%$ of added ${ }^{3} \mathrm{H}_{2} \mathrm{O}$ :

$$
{ }^{3} \mathrm{H}_{2} \mathrm{O} \mathrm{SR}(\mathrm{Bq} / \mathrm{g})=\mathrm{Bq} \text { lost/weight lost. }
$$

Non-specific losses of radioactivity were estimated by comparing ${ }^{14} \mathrm{C}(\mathrm{Bq})$ before and after drying; these remained well within the counting errors $(<1 \%, 2 \mathrm{SD})$.

2. Leucine $f u x$. Leucine flux $(Q)$ was calculated as described by Reeds et al. (1980). The infusion rate of leucine $(I)$ was calculated from the measured $\left[{ }^{3} \mathrm{H}\right]$ leucine content of the infusate. This was estimated for each infusate by preparative ion-exchange chromatography. 
3. Leucine irrevocable breakdown. The irrevocable breakdown of leucine $(B)$ was estimated from the increase, during the infusion, of the ${ }^{3} \mathrm{H}$-labelling of body water. Body water was calculated from body-weight by applying a linear regression equation derived from Kotarbińska's (1969) values for the empty-body-water of fifty female pigs between 28 and $86 \mathrm{~kg}$ body-weight adjusted for the ratio, empty-body water: total body water (TBW) calculated by Houseman et al. (1973). The equation used was:

$$
\frac{\text { body water }}{\mathrm{W}}=0.692(\mathrm{SE} 0.003)-0.0018(\mathrm{SE} 0.00009)(\mathrm{W}(\mathrm{kg})-28) \text {. }
$$

The increase in the SR of body water over the last hour of the infusion was not sufficiently steady for the purpose of deducing $B$ and for this purpose the mean of these values was taken as representing the total amount of ${ }^{3} \mathrm{H}$ released from leucine during $5.5 \mathrm{~h}$ of infusion. Losses of ${ }^{3} \mathrm{H}$ in the breath and in urine during the infusion were not estimated. $B$ was calculated from the increase in ${ }^{3} \mathrm{H}_{2} \mathrm{OSR}$ as follows:

$$
d \mathrm{TBW}{ }^{3} \mathrm{H}_{2} \mathrm{O}=\mathrm{TBW} \times\left[P_{f}{ }^{3} \mathrm{H}_{2} \mathrm{O}-P_{0}{ }^{3} \mathrm{H}_{2} \mathrm{O}\right] \text {, }
$$

where $P_{0}{ }^{3} \mathrm{H}_{2} \mathrm{O}$ and $P_{f}^{3} \mathrm{H}_{2} \mathrm{O}$ are the plasma water SR at the start and after $5.5 \mathrm{~h}$ of the leucine infusion respectively.

The proportion of the dose catabolized was calculated as:

$$
\text { (d TBW }{ }^{3} \mathrm{H}_{2} \mathrm{O}-{ }^{3} \mathrm{H}_{2} \mathrm{O} \text { infused) } /{ }^{3} \mathrm{H} \text { infused as leucine. }
$$

The correction term ${ }^{3} \mathrm{H}_{2} \mathrm{O}$ infused was necessary because the solution of $\left[{ }^{3} \mathrm{H}\right]$ leucine contained a small amount (about $1.5 \%$ ) of ${ }^{3} \mathrm{H}_{2} \mathrm{O}$. This was estimated for each infusion by measuring the ${ }^{3} \mathrm{H}$ that was excluded from the ion-exchange column used to measure the $\left[{ }^{3} \mathrm{H}\right]$ leucine content of the infusate.

4. Calculation of protein synthesis and degradation. The rates of whole-body protein synthesis and degradation were based on measurement of $Q$, calculated as previously described (Reeds et al. 1980) as:

$$
Q=I / R,
$$

where $I$ is expressed as $\mathrm{Bq} / \mathrm{min}$ and $R$ is the $\mathrm{SR}$ of blood leucine $(\mathrm{Bq} / \mathrm{mmol})$.

The rate of leucine incorporation into protein was estimated as $Q-B$. From this the rate of protein synthesis was calculated on the assumption that $1 \mathrm{~g}$ body protein contains 69 mg leucine.

Protein degradation was estimated in two ways, first as the difference between protein synthesis and protein accretion (estimated from $\mathrm{N}$ balance $\times 6.25$ ); second, from the difference between $Q$ (leucine flux) and leucine digested. Digested leucine was estimated from the total $\mathrm{N}$ digested $\times$ the leucine content of the diet. This is probably reasonable because although the digestibility of $\mathrm{N}$ is not in general a good estimator of the digestibility of individual amino acids, it has been observed that the pre-caecal disappearance of leucine is close to the apparent digestibility of $\mathrm{N}$ over the whole gastrointestinal tract (Darcy et al. 1982).

5. Total $N$ flux. This was estimated from the increase in ${ }^{15} \mathrm{~N}$ abundances in urinary urea measured after $24-36 \mathrm{~h}$ of the ${ }^{15} \mathrm{~N}$-labelled yeast administration. $\mathrm{N}$ flux was calculated as ${ }^{15} \mathrm{~N}$ administration rate $/{ }^{15} \mathrm{~N}$ enrichment in urinary urea.

\section{Statistical analysis}

To adjust for the differences in body-weight between animals and to facilitate comparisons between this and the previous experiment the results were scaled in the same units, i.e. per $\mathrm{kg} \mathrm{W}^{0.62}$. An analysis of variance was made using GENSTAT, using regression models in which the effects of animal, period, protein and lysine were estimated. For simplicity in 
presentation, a single SEM was calculated for each variate. Because of unequal numbers of observations for the treatments, this was an approximate SEM, but typically differed by less than $7 \%$ from the smallest or largest individual SEM.

\section{RESULTS AND DISCUSSION}

$$
\text { Body-weight }
$$

The mean weights of the animals are given in Table 2 . The small differences between the mean weights of the animals on the different diets were related to their growth rates; this resulted from the fact that those animals which had the best diets grew fastest and had the highest mean weights in that period.

\section{$N$ intake and excretion}

The intakes were virtually identical in the two LP diets but with the supplemented HP $(\mathrm{HP}+)$ diet there were some small food refusals so that the animals receiving this diet absorbed significantly less $\mathrm{N}$ than intended. The mean digestibility of $\mathrm{N}$ was 0.75 with no significant differences with protein concentration or lysine supplementation. The rate of urea excretion was halved by doubling the lysine content of the LP diet, but with the HP diet the same supplement of lysine reduced urea excretion by only half as much $(0.8 v$. $1.7 \mathrm{~g} / \mathrm{kg} \mathrm{W}^{0.62}$ ). As a result, the addition of lysine to the LP diet almost doubled the rate of $\mathrm{N}$ retention whereas with the HP diet it was without effect. This is in contrast to the results of the previous experiment (Fuller et al. 1987a) in which the same diets were given, when $\mathrm{N}$ retention was higher with diet $4(\mathrm{HP}+)$ than with diet $3(\mathrm{HP}-)$. However, there were some differences in food intake between the experiments and when all the results are plotted together, as in Fig. 2, there is close agreement between the experiments with diets 1 (LP-) and 3 (HP-), which taken together suggest a marginal efficiency of $N$ utilization of the unsupplemented protein of 0.32 . With the supplemented diet it appears that $\mathbf{N}$ retention increased with the amount of $\mathrm{N}$ digested up to $4 \mathrm{~g} / \mathrm{kg} \mathrm{W}^{0.62}$, but that higher rates of $\mathrm{N}$ supply resulted in a proportionately smaller increase in $\mathrm{N}$ retention (Expt 1; Fuller et al. $1987 \mathrm{a})$. The highest value, $2 \cdot 45 \mathrm{~g} / \mathrm{kg} \mathrm{W}^{0.62}(26 \mathrm{~g} / \mathrm{d}$ at the mean body-weight $)$, is likely to be close to the animal's maximum potential rate of protein accretion. When all the values are seen together in this way it is the results for diet 4 in Expt 2 which appear to be anomalous. The only difference between the protocols of the two experiments was that, for practical reasons, pigs were fed twice daily in Expt 1 and once hourly in Expt 2; there does not seem to be any evidence from published work that pigs fed more frequently use dietary protein less efficiently.

\section{Digestibility of total $N$ and of ${ }^{15} N$ at the terminal ileum}

There were no significant differences amongst the three pigs in the mean ${ }^{15} \mathrm{~N}$ enrichment of ileal digesta nor was there any significant increase with time after the start of administration. The mean enrichment was $0.00389 \mathrm{~g}$ atoms ${ }^{15} \mathrm{~N} / 100 \mathrm{~g}$ atoms $\mathrm{N}$. From the $\mathrm{Cr}:{ }^{15} \mathrm{~N}$ ratio in the digesta, the mean digestibility of ${ }^{15} \mathrm{~N}$ was estimated to be 0.87 (SE 0.022). The mean digestibility of total $\mathrm{N}$ at the terminal ileum was similarly estimated to be 0.73 (SE 0.020).

\section{Urea synthesis}

The rates of urea synthesis, estimated from the constant infusion of $\left[{ }^{14} \mathrm{C}\right]$ urea, are given in Table 3. Addition of lysine to both diets substantially reduced urea synthesis, which was twice as great with the higher rate of protein intake. By comparing these values with the rates of urea excretion shown in Table 2, it is clear that more urea was synthesized than was excreted in the urine. There were no significant differences between diets in the ratio, urea 
Protein turnover in growing pigs

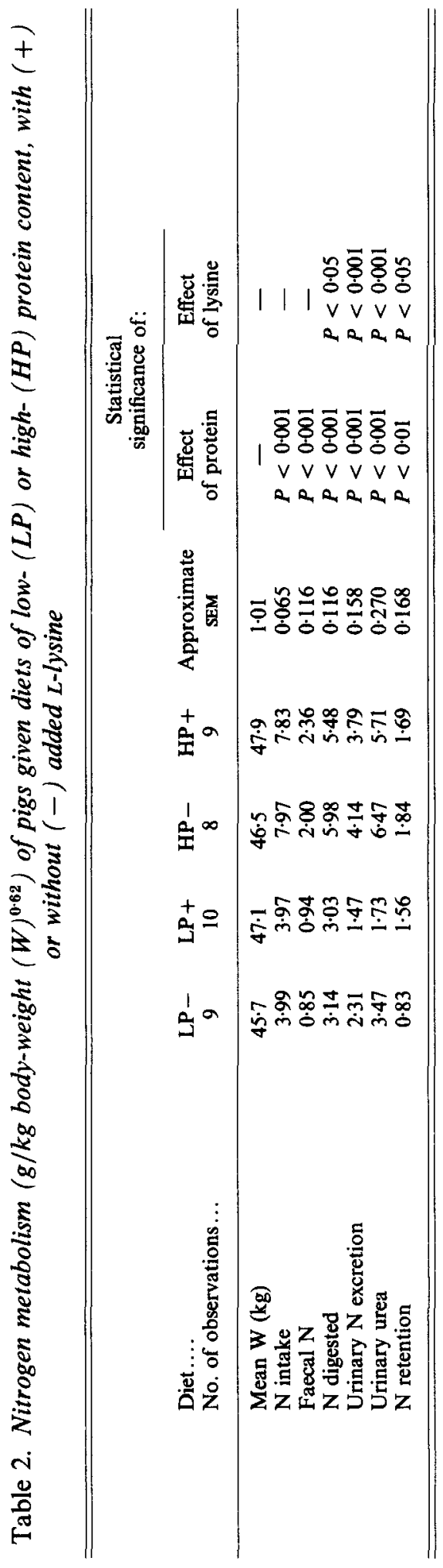


M. F. FULLER AND OTHERS

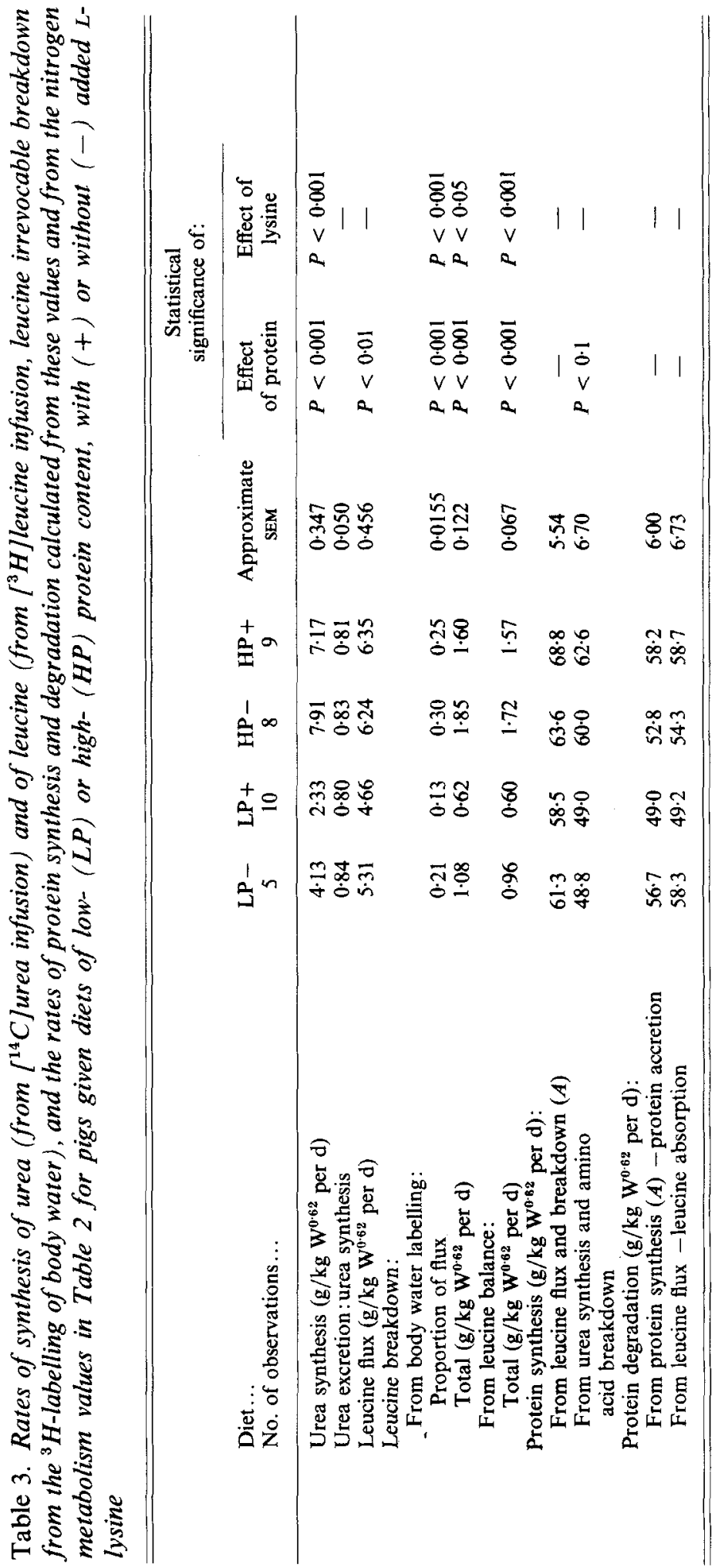




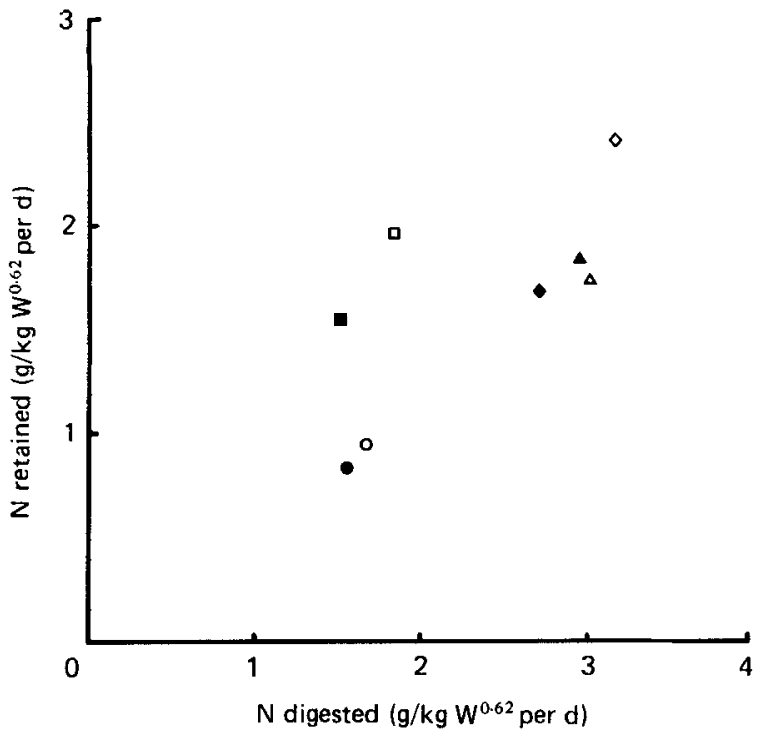

Fig. 2. The relation between nitrogen retained and $N$ digested in this $(\mathbf{O}, \mathbf{a}, \boldsymbol{\Delta}, \bullet)$ and the previous experiment (Fuller et al. 1987a; $\bigcirc, \square, \triangle, \diamond) .(O, \bigcirc)$ Low-protein without lysine; $(\square, \square)$, low-protein with lysine; $(\triangle, \Delta)$, high-protein without lysine; $(\diamond, \diamond)$, high-protein with lysine. For details of diets, see Table 1 and Fuller et al. (1987a). W, body-weight.

Table 4. Total amino acid flux estimated from leucine flux $/ 0 \cdot 069$, urea flux/fractional amino acid breakdown and ${ }^{15} \mathrm{~N}$-labelling of urinary urea in pigs given diets of low- (LP) or high(HP) protein content, with ( + ) or without ( - ) added L-lysine

(Values are means based only on those animals in which all these methods were compared simultaneously)

\begin{tabular}{|c|c|c|c|c|c|c|c|c|}
\hline \multirow[b]{2}{*}{$\begin{array}{l}\text { Diet ... } \\
\text { No. of observations... }\end{array}$} & \multirow[b]{2}{*}{$\frac{\text { LP - }}{6}$} & \multirow[b]{2}{*}{$\underset{5}{\mathrm{LP}+}$} & \multirow[b]{2}{*}{$\begin{array}{c}\mathrm{HP}- \\
4\end{array}$} & \multirow[b]{2}{*}{$\underset{5}{\mathrm{HP}}+$} & \multirow[b]{2}{*}{$\begin{array}{l}\text { Approximate } \\
\text { SEM }\end{array}$} & \multicolumn{2}{|c|}{$\begin{array}{c}\text { Statistical } \\
\text { significance of: }\end{array}$} & \multirow[b]{2}{*}{$\begin{array}{l}\text { Inter- } \\
\text { action }\end{array}$} \\
\hline & & & & & & $\begin{array}{l}\text { Effect } \\
\text { of protein }\end{array}$ & $\begin{array}{l}\text { Effect } \\
\text { of lysine }\end{array}$ & \\
\hline \multicolumn{9}{|l|}{ Total amino acid flux: } \\
\hline From leucine flux & $66 \cdot 4$ & $68 \cdot 3$ & $88 \cdot 3$ & $94 \cdot 5$ & $9 \cdot 48$ & $P<0.05$ & - & - \\
\hline $\begin{array}{l}\text { From urea flux } \\
\text { and leucine breakdown }\end{array}$ & $59 \cdot 8$ & $56 \cdot 2$ & $57 \cdot 5$ & $82 \cdot 7$ & $8 \cdot 54$ & - & - & $P<0.1$ \\
\hline From ${ }^{15} \mathrm{~N}$ urea & $46 \cdot 4$ & $43 \cdot 8$ & $58 \cdot 8$ & $62 \cdot 1$ & $7 \cdot 20$ & $P<0.1$ & - & - \\
\hline $\begin{array}{l}\text { Proportion of }{ }^{15} \mathrm{~N} \text { dose } \\
\text { excreted in urine }\end{array}$ & $26 \cdot 3$ & $14 \cdot 8$ & $32 \cdot 4$ & $38 \cdot 4$ & $4 \cdot 62$ & $P<0.01$ & - & $P<0.1$ \\
\hline
\end{tabular}

synthesis: excretion; the mean proportion was 0.82 (SEM 0.050) (Table 3) although the absolute difference between the daily rates of urea synthesis and excretion $\left(\mathrm{g} / \mathrm{kg} \mathrm{W}^{0.62}\right)$ was greater $(P<0.05)$ with the HP diet $(1.45$ (SE 0.344)) than with the LP $\operatorname{diet}(0.63$ (SE 0.327$))$.

\section{$\mathrm{Q}$ (leucine flux)}

$Q$ was significantly greater with the higher protein supply, but was not altered significantly by the addition of lysine to either diet. On all diets $Q$ exceeded the leucine apparently digested by a similar amount, approximately $3 \cdot 7 \mathrm{~g} / \mathrm{kg} \mathrm{W}^{\mathbf{0 . 6 2}}$ per $\mathrm{d}$. 


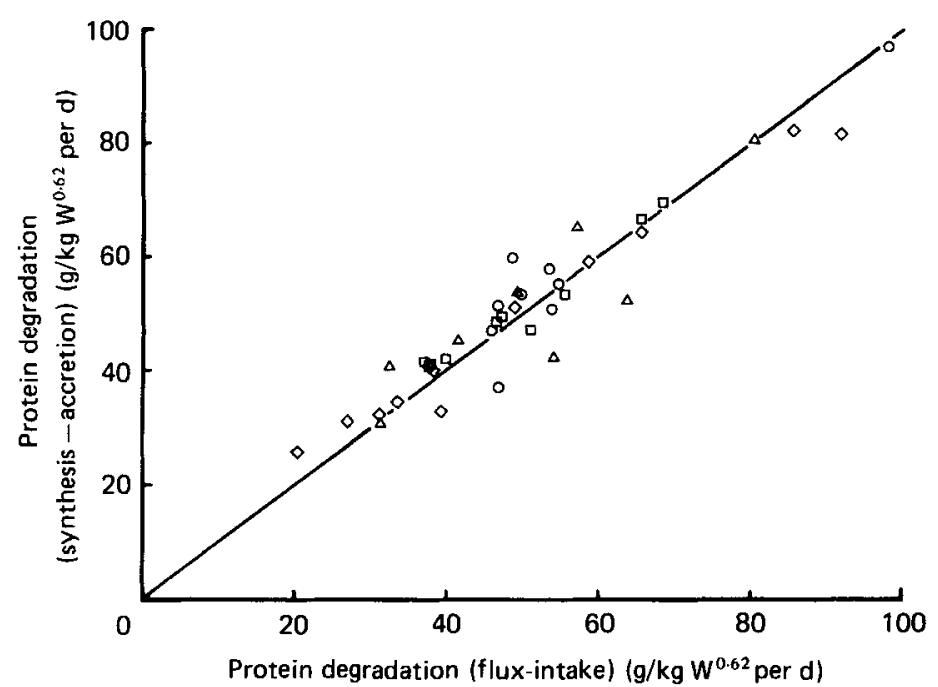

Fig. 3. The relation between the rates of whole-body protein degradation estimated from protein synthesis (based on leucine flux and oxidation) minus protein accretion (from $\mathrm{N}$ balance) and leucine flux minus leucine absorbed. $(\diamond)$, Low-protein without lysine; $(\square)$, low-protein with lysine; $(\triangle)$, highprotein without lysine; (O), high-protein with lysine. For details of diets, see Table 1 and Fuller $e t$ al. $(1987 a)$. (-), Indicates equality. W, body-weight.

\section{B (leucine irrevocable breakdown)}

$B$, expressed both as $\mathrm{g} / \mathrm{kg} \mathrm{W}^{0.62}$ and as a proportion of $Q$, is given in Table 3 . The addition of lysine to the LP diet substantially reduced $B$, and had a small effect with the HP diets. The proportional reduction in $B$ on lysine supplementation was similar to that in urinary urea and urea synthesis and estimates of $B$ made from body-water labelling were in close agreement with those made, over a longer period, from $\mathrm{N}$ balance.

\section{Total amino acid fux}

The total flux of amino acids was estimated in three ways: first, from $Q$ divided by 0.069 , the proportion of leucine in whole-body protein; second from the rate of urea synthesis divided by the fractional breakdown of amino acid, using the fractional breakdown of leucine as the representative tracer amino acid; third, from the ${ }^{15} \mathrm{~N}$ labelling of urinary urea. These comparisons, for the twenty infusions for which results were obtained with all three methods, are set out in Table 4, together with values for ${ }^{15} \mathrm{~N}$ excretion. There were substantial and systematic differences between the three estimates but they all show the same effects of dietary treatment : that the total amino acid flux was significantly greater on the HP than on the LP diets. The addition of lysine to the LP diet had little effect on total amino acid flux but when the HP diet was supplemented with lysine there was, irrespective of the method, a tendency for it to increase. However, none of these changes was significant.

\section{Protein synthesis and degradation}

The estimates of whole-body protein synthesis made from the values for leucine metabolism are given in Table 3 . The rate of protein synthesis was not significantly changed by the addition of lysine to either diet. There was a tendency for the rate of protein synthesis to be higher with the greater protein supply but the effect was not significant. 
Table 5. The concentration of leucine, insulin and cortisol in the blood of pigs given diets of low- $(L P)$ or high- $(H P)$ protein content, with $(+)$ or without $(-)$ added L-lysine

\begin{tabular}{|c|c|c|c|c|c|c|c|c|}
\hline \multirow[b]{2}{*}{$\begin{array}{l}\text { Diet... } \\
\text { No. of observations... }\end{array}$} & \multirow[b]{2}{*}{$\underset{8}{\mathrm{LP}-}$} & \multirow[b]{2}{*}{$\begin{array}{c}\text { LP+ } \\
7\end{array}$} & \multirow[b]{2}{*}{$\mathrm{HP}-$} & \multirow[b]{2}{*}{$\underset{8}{\mathrm{HP}+}$} & \multirow[b]{2}{*}{$\begin{array}{l}\text { Approximate } \\
\text { SEM }\end{array}$} & \multicolumn{3}{|c|}{$\begin{array}{c}\text { Statistical } \\
\text { significance of : }\end{array}$} \\
\hline & & & & & & $\begin{array}{c}\text { Effect } \\
\text { of protein }\end{array}$ & $\begin{array}{l}\text { Effect } \\
\text { of lysine }\end{array}$ & Interaction \\
\hline Blood leucine & 249 & 226 & 362 & 334 & $12 \cdot 0$ & $P<0.001$ & $P<0.05$ & - \\
\hline Blood insulin & $13 \cdot 0$ & $16 \cdot 2$ & $17 \cdot 2$ & $22 \cdot 8$ & $3 \cdot 45$ & $P<0.1$ & - & - \\
\hline Blood cortisol & $26 \cdot 4$ & $31 \cdot 2$ & $51 \cdot 5$ & $36 \cdot 9$ & $5 \cdot 70$ & $P<0.05$ & - & $P<0.1$ \\
\hline
\end{tabular}

Protein degradation was estimated both from the difference between protein synthesis and protein accretion and from the difference between $Q$ (leucine flux) and leucine digested. There was close agreement between these two sets of estimates, as shown in Fig. 3. The dominant term in both estimates is $Q$ and the closeness of agreement is in essence a reflection of how closely $B$ (irrevocable loss of leucine), estimated from body-water labelling, was related to the total $\mathrm{N}$ excretion. There was no significant difference between the diets in the rate of protein degradation although the tendency was for lysine addition to the LP diet to reduce protein degradation but to increase it with the HP diet (Table 3). Clearly, the substantial proportionate increase in $\mathrm{N}$ retention achieved by supplementing the LP diet with lysine did not occasion any large perturbation in the rate of protein turnover.

\section{Blood leucine concentration}

Blood leucine concentration was significantly higher with the HP diet than with the LP diet; lysine supplementation reduced blood leucine concentration significantly $(P<0.05)$ on both diets (Table 5).

\section{Blood insulin}

Blood insulin concentration tended to be increased by both the protein content of the diet $(P<0 \cdot 1)$ and also, though not significantly, by lysine supplementation (Table 5).

\section{Blood cortisol}

Blood cortisol concentration was significantly $(P<0.05)$ increased by the protein content of the diet (Table 5). The effects of lysine supplementation, however, differed $(P<0 \cdot 1)$ with the protein content of the diet; supplementation of the LP diet increased blood cortisol, whereas with the HP diet the effect of supplementation was to reduce blood cortisol.

\section{GENERAL DISCUSSION}

The aim of these experiments was to increase the rate of protein accretion in two distinct ways - one by increasing protein intake, the other by improving protein quality and to determine whether these increases in protein accretion were achieved by similar changes in the rates of protein synthesis and degradation. The experiments were made with controlled food intake so that protein quality and quantity should not be confounded. In this respect our experiment differed from those made in rats by Roeder \& Broderick (1981) in which the addition of lysine and threonine to wheat gluten resulted in a $50 \%$ increase in voluntary food intake. They reported that after the rats had been eating the experimental diets for $10 \mathrm{~d}$ the fractional rates of both protein synthesis and degradation in skeletal muscle were increased (by 2.3- and 1.7-fold respectively), but it is not possible to determine 
from their results to what extent these increases were brought about by the change in protein quality per se and to what extent by the accompanying increase in the intakes of protein and of non-protein energy, both of which we have shown to increase whole-body protein synthesis rates in growing pigs (Reeds et al. 1980; 1981). This difficulty applied also to the experiments of Hayase \& Yoshida (1980) who, like Roeder \& Broderick (1981), used $\mathrm{H}^{14} \mathrm{CO}_{3}$ to label body proteins. They reported that with the dietary proteins of higher quality the decline in the SR of protein in both liver and kidney was greater, indicating higher rates of protein synthesis. They also reported increases in the rate of decline of total radioactivity in liver proteins, indicating a greater rate of protein catabolism, on changing the dietary protein source from casein to the low-quality proteins gelatin and gluten. However, the decline in the total radioactivity of skeletal muscle was not affected by dietary protein quality, although the rate of urinary $N^{\tau}$-methylhistidine excretion, another measure of skeletal muscle protein degradation, was significantly higher with a high-quality protein (whole egg) than with gelatin or gluten. As mentioned previously, food intake was not controlled (or reported) in these experiments and it is accordingly not possible to disentangle the effects of protein quality and food intake. However, Omstedt et al. (1978) controlled the food intakes of rats to which they gave diets containing proteins of different quality. They found that urinary $N^{\top}$-methylhistidine excretion increased with dietary protein quality. Those results suggest that the faster growth brought about by improvement in protein quality was associated with an increase in muscle protein catabolism and therefore with an even greater increase in muscle protein synthesis. However, it is not clear to what extent changes in one tissue (in this instance skeletal muscle) are representative of those in the whole body.

Each method of estimating whole-body protein synthesis and degradation involves particular assumptions and it seemed possible that the nature of the dietary changes which are used to induce changes in protein accretion might have invalidated some of these assumptions and led to erroneous conclusions. For this reason we elected to use three methods, each of which involves a different set of assumptions.

The method of measuring body protein turnover from the turnover of blood free leucine has been used extensively. It rests on two main assumptions: first, that the SR of blood free leucine is a close reflection of leucine labelling at the sites of both protein synthesis and leucine catabolism; second, that in its turnover and catabolism leucine is representative of the other amino acids. It is recognized that the first assumption may not be valid and probably underestimates the rate of turnover of body protein. However, provided that the relation between the labelling of blood free leucine and of leucine at the sites of metabolism remains constant the method will still give valid information on changes in protein turnover in response to alterations of diet. The second assumption, that leucine metabolism reflects that of the other amino acids, can only be valid if the dietary protein is reasonably well balanced, at least in so far that leucine is neither grossly deficient nor excessive relative to other amino acids. The fact that diets 1 and 3 were deliberately made very deficient in lysine means that the division of lysine between irrevocable catabolism and protein synthesis was likely to be very different from that of other amino acids. With this exception, however, the dietary protein was reasonably well balanced, with a proportion of leucine $(6.72 \mathrm{~g} / 16 \mathrm{~g} \mathrm{~N})$ very close to that in body protein which contributed half to two-thirds of the total leucine flux $(Q)$. This last assumption, that leucine is a representative amino acid in the extent of its catabolism, is also implicit in the second method, based on urea synthesis and leucine catabolism. This approach involves the additional assumption that urea synthesis (rather than urea excretion) is a close reflection of total amino acid catabolism.

The observation that urea synthesis exceeded urea excretion by a factor of approximately 1.2 gives rise to the question of whether urea synthesis or excretion is the appropriate 
numerator in the calculation of total amino acid flux. The difference between these quantities is assumed to be the amount of urea metabolized presumably in the gut, and the urea synthesized from this recycled $\mathbf{N}$ does not therefore represent amino acid degradation. On the other hand, it is well known that urea can be taken up by the gut, and its $\mathrm{N}$ incorporated into microbial protein excreted in the faeces. Using urinary urea excretion for the estimate of total amino acid degradation could therefore result in an underestimate of amino acid flux. The validity of the third method based on the labelling of urea following the administration of ${ }^{15} \mathrm{~N}$-labelled amino acids rests on the single main assumption that the distribution of the ${ }^{15} \mathrm{~N}$ label between urea and protein synthesis is the same as that of total amino N (Fern et al. 1985a, b).

The three methods gave systematically different values for total amino acid flux. The method based on urea synthesis and leucine catabolism gave a value for total amino acid flux of 0.86 (SD 0.03 ) of the leucine value suggesting that on average the proportion of leucine flux $(Q)$ that was catabolized was higher than that of total N. Surprisingly, the lowest value was obtained with the ${ }^{15} \mathrm{~N}$-method which from some points of view could have been regarded as using the most representative tracer (an amino acid mixture). This method gave a value for amino-N flux that was 0.66 (SD 0.02) of the value derived from $Q$ alone. In calculating the ${ }^{15} \mathrm{~N}$ results it was assumed that the ${ }^{15} \mathrm{~N}$ entering the flux was the amount fed. Although we obtained information on the apparent digestibility at the terminal ileum of ${ }^{15} \mathrm{~N}$ it cannot be assumed that this gives an appropriate correction to the rate of ${ }^{15} \mathrm{~N}$ administration. The pre-treatment of the yeast protein was intended to make the ${ }^{15} \mathrm{~N}$ labelled amino acids highly digestible and it seems likely that some proportion, perhaps a large proportion, of the ${ }^{15} \mathrm{~N}$ in ileal digesta was not of immediate dietary origin. Some could have been in digestive secretions synthesized during the time-course of the administration: it has been shown, for instance, that pancreatic proteins can become labelled within minutes of an intravenous injection of labelled amino acid (Simon et al. 1983). Some ${ }^{15} \mathrm{~N}$ could have been in urea which equilibrates between the plasma and the water of the digesta. Some could have been in microbial proteins. There is considerable microbial activity in digesta at the terminal ileum and this would effectively sequester ${ }^{15} \mathrm{~N}$ from endogenous secretions, whether of protein or urea. In view of these uncertainties, we prefer to suggest that the true rate of ${ }^{15} \mathrm{~N}$ entry into the body $\mathrm{N}$ pool was between 87 and $100 \%$ of that given orally, and probably nearer the latter. At worst, our estimate of amino acid flux from ${ }^{15} \mathrm{~N}$ urea labelling would thus underestimate the flux by $15 \%$. However, the route of administration of ${ }^{15} \mathrm{~N}$-labelled amino acids can also have an important bearing on the estimate of total $\mathrm{NH}_{2}-\mathrm{N}$ flux (Fern et al. 1985a). By using oral administration it is possible that the hepatic pool of free amino acids will have a higher isotope abundance than total body free $\mathrm{NH}_{2}-\mathrm{N}$ and hence isotope will pass preferentially to urea. Certainly Fern et al. (1985 a) found that, when based on urea labelling, oral ${ }^{15} \mathrm{~N}$-labelled alanine, glutamate, glutamine, aspartate, glycine and lysine gave values for total $\mathrm{NH}_{2}-\mathrm{N}$ flux that were $0 \cdot 70$ (SD 0.02 ) of the values obtained with intravenously administered amino acids. Only with leucine, an amino acid that is transaminated in the liver to only a very small extent, were the values similar. The corollary is that the proportion of the dose of ${ }^{15} \mathrm{~N}$ excreted will be higher than that of leucine and on average this was true, with the value for leucine being 0.75 of that for ${ }^{15} \mathrm{~N}$.

The most important point to emerge from this comparison was that all three methods led to the same conclusion; that increasing $\mathrm{N}$ retention by improving the quality of dietary protein had no significant effect either on total amino acid flux or on body protein synthesis. It appears therefore that the doubling in the rate of protein accretion resulting from lysine supplementation was brought about primarily by a reduction in body protein breakdown. Additional protein increased amino acid flux by 29 (SE 3) \% with the poor- 
quality protein and by 43 (SE 5) \% with the lysine-supplemented diet, suggesting that body protein synthesis increased more when a better amino acid mixture was supplied to the animal.

The authors are grateful to Dr D. Halliday for providing ${ }^{15} \mathrm{~N}$-labelled yeast. They thank Mr R. Smart and Miss R. Fordyce for chemical analyses and Mr M. Franklin for statistical analysis.

\section{REFERENCES}

Agricultural Research Council (1981). The Nutrient Requirements of Pigs. Slough: Commonwealth Agricultural Bureaux.

Bassett, J. M. \& Thorburn, G. D. (1971). Journal of Endocrinology 50, 59-74.

Davidson, J., Mathieson, J. \& Boyne, A. W. (1970). Analyst 95, 181-193.

Darcy, B., Laplace J. P. \& Duée, P. H. (1982). Annales de Zootechnie 29, 137-145.

Fawcett, J. K. \& Scott, J. E. (1960). Journal of Clinical Pathology 13, 156-159.

Fern, E. B., Garlick, P. J. \& Waterlow, J. C. (1985a). Clinical Science 68, 271-282.

Fern, E. B., Garlick, P. J. \& Waterlow, J. C. (1985b). Human Nutrition: Clinical Nutrition 39C, 85-99.

Fuller, M. F., Cadenhead, A., Mollison, G. \& Seve, B. (1987 a). British Journal of Nutrition 58, $277-285$.

Fuller, M. F., Cadenhead, A., Reeds, P. J., Mollison, G. \& Seve, B. (1987b). In Energy Metabolism of Farm Animals, European Association for Animal Production, publication no. 32, pp. 2-5 [P. W. Moe, H. F. Tyrell and P. J. Reynolds, editors]. Totowa: Rowman \& Littlefield.

Hayase, K. \& Yoshida, A. (1980). Nutrition Reports International 22, 235-244.

Houseman, R. A., McDonald, I. \& Pennie, K. (1973). British Journal of Nutrition 30, $149-156$.

Kotarbińska, M. (1969). Badania nad Przemiana Energii u Rosnacych Świń. Wlasne Instytut Zootechniki, Wrocław, no. 238.

Marsh, W. H., Fingerhut, B. \& Miller, H. (1965). Clinical Chemistry 11, 624-627.

Millward, D. J., Garlick, P. J. \& Reeds, P. J. (1976). Proceedings of the Nutrition Society 35, 339-349.

Omstedt, P. T., Kihlberg, R., Tingrall, P. \& Shenkin, A. (1978). Journal of Nutrition 108, 1877-1882.

Preston, T. \& East, B. W. (1982). The Measurement of ${ }^{15} \mathrm{~N}$ in Biological Samples with Particular Reference to Whole Body Protein Turnover Studies. Scottish Universities Research and Reactor Centre, publication no. 70/82. East Kilbride: Scottish Universities Research and Reactor Centre.

Preston, T. \& Owens, N. J. P. (1983). Analyst 108, 971-977.

Read, W. W. C., Harrison, R. A. \& Halliday, D. (1982). Analytical Biochemistry 123, 249-254.

Reeds, P. J., Cadenhead, A., Fuller, M. F., Lobley, G. E. \& McDonald, J. D. (1980). British Journal of Nutrition 43, 445-455.

Reeds, P. J., Fuller, M. F., Cadenhead, A., Lobley, G. E. \& McDonald, J. D. (1981). British Journal of Nutrition 45, 539-546.

Roeder, R. A. \& Broderick, G. A. (1981). Nutrition Reports International 24, 361-369.

Simon, O., Zebrowska, T., Bergner, H. \& Münchmeyer, R. (1983). Archiv für Tierenährung 33, 9-22. 